\title{
MEK 1/2 Inhibitor AS703988/MSC2015103B
}

National Cancer Institute

\section{Source}

National Cancer Institute. MEK 1/2 Inhibitor AS703988/MSC2015103B. NCI Thesaurus.

Code $C 98832$.

An orally bioavailable small-molecule inhibitor of mitogen-activated protein kinase kinase (MAP2K, MAPK/ERK kinase, or MEK) 1 and 2 with potential antineoplastic activity. MEK1/2 inhibitor AS703988/MSC2015103B selectively binds to and inhibits the activity of MEK1/2, preventing the activation of MEK1/2-dependent effector proteins and transcription factors, which may result in the inhibition of growth factor-mediated cell signaling and tumor cell proliferation. MEK1/2 are dual-specificity threonine/tyrosine kinases that play key roles in the activation of the RAS/RAF/MEK/ERK pathway that regulates cell growth and are often upregulated in a variety of tumor cell types. 